\title{
The Challenge of Park Development
}

by R. L. Carter, Department of Natural Resources, Regina

As another summer approaches, all park planners across North America are again aware, as they have been each year for the past ten years, that all the new facilities and all the new methods adopted to increase their ability to handle people in the parks will be inadequate in the face of the number of visitors expected.

The accompanying chart illustrates the increase in park use since 1945. On the average, attendance in the Canadian national parks has increased by approximately a quarter of a million per year, at Banff NationalPark by more than 50,000 people per year, and at Prince Albert National Park by about 10,000 people per year. Park planners fear such increases because they have never caught up with the demand, and they fear that the park environment will be spoiled if sufficient public money is not made available in time to provide facilities required to handle these crowds of people. Every new picnic area, every new beach, every building generates its own popularity, and as the word gets around, more people flock to the developed spots.

One of the factors that increases park attendance is the increase in leisure time. An established work week of 40 hours became general soon after the war. By 1985 it is believed that we shall have a work week of 32 hours, with increased paid vacations, perhaps one week of paid vacation every three months, and one month's additional paid vacation every year. The attitude that hard work is a virtue and idleness is sinful is likely to change as the opportunities for increased leisure brought by modern technology increase in number, and the "protestant ethic," as defined by Max Weber, dies out of North American society.

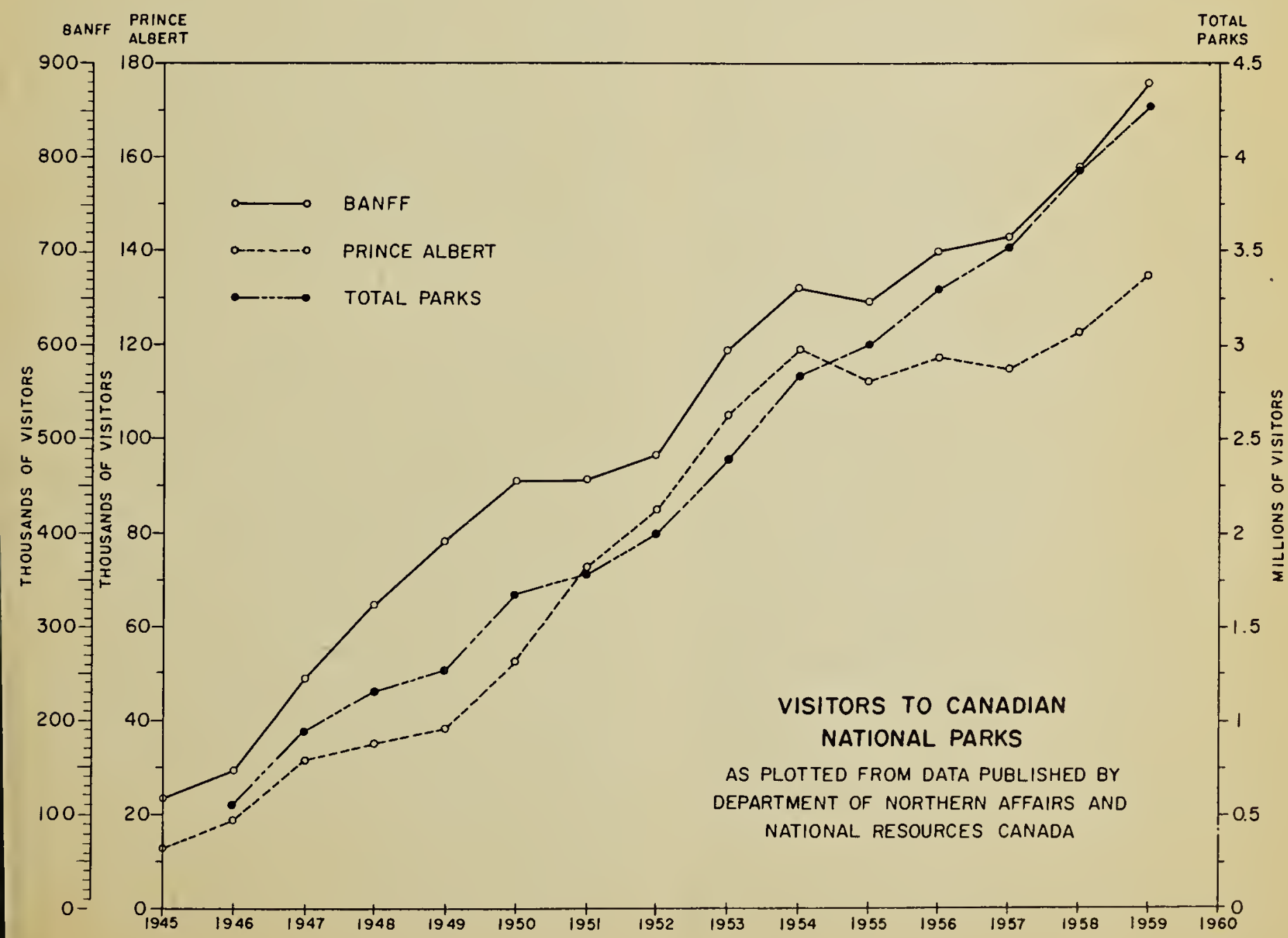


Our tremendous mobility is a second factor influencing the demand for outdoor recreation on this continent. Marion Clawson, of Resources for the Future Inc., has explained that in 1956 North Americans were generally travelling 5,080 miles per year, and he felt that the average annual per capita travel in the U.S. would reach 7,700 miles in 1985 and about 9,000 per year in the year 2000. Saskatchewan residents are the most mobile in Canada, if mobility is measured by the number of people per vehicle owned. There are 2.7 people per vehicle in this province, as compared with the Canadian average of 3.5 people per vehicle. There is every evidence that we enjoy this mobility, and it looks as though the number of vehicles owned by the Canadian population will increase fairly steadily, perhaps reaching a figure of two people for every vehicle owned by the 1980's.

The income level, of course, strongly influences use of leisure time. The increase in real income per capita is close to $2 \%$ per year, and although it is hard to determine how much money is actually spent on recreation, probably beitween $1 / 3$ and $1 / 2$ of all money available for recreation is spent in the out-of-doors.

The final factor to consider in predicting the future use of our parks is the increase in population. The population of Saskatchewan grew by $2.4 \%$ from 1956 and 1959. We now have about 902,000 people. Over the same period, the population of Canada increased by about $8 \%$. Therefore, although we are not likely to suffer the same strain on our parks as other parts of Canada, we must prepare for a general increase, which, when reviewed in the light of the few good sites available near the places where people live, makes park planning in Saskatchewan difficult. Because of our peculiar geographical settingmany people in the south with few recreational resources and few people in the north but ample poitential for recreational use-the pressure applied by the above factors is magnified by the lack of good sites for large scale provincial parks.

There are three groups of parks in which the Provincial Government has a share of responsibility in Saskatchewan. The provincial parks, such as Moose Mountain, Duck Mountain, the Battlefords, are all vacation areas and areas used by the day tripper. Though their resources for recreation are not as abundant as that of the Prince Albert National Park, they are located in our best scenery. Generally speaking, they cater to Saskatchewan residents, and visitors from outside the province are few in proportion. Secondly, the regional parks, which will be scattered throughout the province when the regional parks scheme gets fully underway, cater to day trippers travelling not more than an hour from home. The Provincial Government gives financial assistance, but the affairs of each parkconstruction, maintenance, etc., are supervised by a regional park board of local people. Under the Act, the province shares the capital costs and assists with planning when asked. In the third category are the highway picnic sites, the historic sites, TransCanada picnic and camp grounds, etc. which cater to the travelling public.

Most people are familiar with the older parks, but perhaps few know of the facilities to be provided at Echo Valley, Buffalo Pound Lake, Pike Lake, and later at the South Saskatchewan Reservoir. These new parks will take some of the pressure off the populated triangle bounded by $\mathrm{Re}-$ gina, Swift Current, and Saskatoon, which has been singularly lacking in recreational opportunities in the past. It may be that the province is trying to make "a silk purse out of a sow's ear" at Pike Lake for the Saskatoon people who: have so few recreational resources close to that city, but at Echo Valley, for example, the peninsula which exitends out between Echo and Pasqua Lakes has some of the finest natural beaches in the south part of the province, and with the magnificent backdrop of the Qu'Appelle Valley, should prove to be one of our most beautiful parks, especially atitractive to Regina residents. We are fortunate, indeed, to have a reserve of recreational land waiting for development on the South Saskatchewan Reservoir. There are many states in the U.S. at a complete loss how to meet the pressures I have mentioned above. At least in Saskatchewan we can see ahead for perhaps 50 years and know that we will 
have the lands available for development, even if we cannot expect adequate funds to make the best use of them.

The problems of pressure and finances are not the only ones which face the park planner in Saskatchewan. A tradition has grown up that part of our park lands should be sub-divided and leased for private cottage development; this is a very inefficient use of the land, compared with the use the public would make of an area of like frontage.

It is becoming extremely expensive to acquire land for new Provincial Park areas in Saskatchewan in the south part of the Province. Not only must the Province spend copious funds in developing parks, it must first spend many thousands of dollars in acquiring land on which to place each park. Though this problem is not proving insurmountable, the resources of a limited budget for park construction are obviously curtailed by funds required for the acquisition of land.

Lastly, and all too frequently, a lack of respect for the facilities provided is leading to tremendous problems in maintenance throughout our park system. No person in the province would wish to have his every action watched by a member of a park's staff, yet the amount of vandalism, the destruction of trees, the lack of attention to fires, the deliberate destruction of buildings, picnic tables, etc., might make this expensive policing necessary.

One other problem of special interest to the readers of this magazine must be faced in the near future. Little attenition has been given, so far, to the creation of true wilderness areas. We work for wilderness preservation not primarily for the right of a minority to have the kind of fun it prefers, but rather to ensure for everyone the perpetuation of areas where human enjoymenit and apprehension of the inter-relations of the whole community of life are possible, and to preserve for all the freedom of choosing to know the primeval if they so wish. Nothing like Bill S. 174, placed before U.S. Congress in January, 1961, has appeared in Canadian Legislation. I cannot do better than to quote from the preamble to this Bill:

"A wilderness, in contrast with those areas where man and his own works dominate the landscape, is hereby recognized as an area where the earth and its community of life are untrammeled by man, where man himself is a visitor who does not remain. An area of wilderness is further defined to mean in this Act an area of undeveloped Federal land retaining its primeval character and influence, without permanent improvements or human habitation, which is protected and managed so as to preserve its natural condition and which (1) generally appears to have been affected primarily by the forces of nature, with the imprint of man's work substantially unnoticeable; (2) has outstanding opportunities for solitude or a primitive, unconfined type of recreation; (3) is of sufficient size as to make practicable its preservation and use in an unimpaired conditinn: and (4) may also contain ecological, geological, or other features of scientific, educational, scenic or historical value." In northern Saskatchewan particularly, we have such areas. We shall not have them for many more years. Our roads are penetrating further and further north each year. Our logging operations are extending outwards from the inhabitated part of the Province. Tourists and campers are travelling northwards, certainly to enjoy the scenery, the fishing and the hunting, but not for the sole purpose of enjoying the solitude and the charm of the natural environment which this definition envisaged. We have the opportunity now to set aside areas to preserve these primeval characteristics. In ten, even in five years' time, the opportunity may be lost to us. Whereas parts of our parks, particularly Nipawin Provincial Park and LaRonge Provincial Park, approach the definition, we have not yet considered wilderness in its own right, and must do so before very long. Where we have scenery of special character, such as the badlands of the Big Muddy country-which, although altered bv grazing and other uses by man, are nevertheless close to the primeval in character-we should consider setting aside small representative areas of this landscape and exclude man's modifying influences from them. 